\title{
Evaluation on the Financing Cost of Listed Companies in China
}

\author{
Xiaojun Deng \\ College of Economics and Business Management \\ Xi'an Shiyou University \\ Xi'an, Shaanxi 710065
}

\author{
Yixin Wang \\ College of Economics and Business Management \\ Xi'an Shiyou University \\ Xi’an, Shaanxi 710065
}

\begin{abstract}
In the light of the phenomenon that our country's listed companies prefer equity financing, a financing cost measurement index system with perspectives of operating risk, financial risk, operating efficiency and development potential is established according to the nature of financing cost in this paper. And efforts are made to assess the application value of the system. The empirical results of 44 listed companies in Shanghai and Shenzhen stock markets show that the most influential factor for corporate financing cost is the operating risk, followed by financial risk and operating efficiency and the development potential. The operating risk factor scores bellow $\mathbf{- 1 . 1 7}$, financial risk below 5, operating efficiency below -2.8 and development potential below 2 points.
\end{abstract}

Keywords-core competitiveness; financial analysis system; application

\section{The Status QUO OF THE FINANCING OF Listed COMPANIES IN CHINA}

Our country's listed companies generally have a relatively strong preference for equity financing. From the TABLE I, it can be seen that in the financing structure of listed companies, equity financing accounts for relatively large proportion of the total amount of financing, ranking on the top of all financing methods. Therefore, it is concluded that the equity financing becomes the main means of financing of listed companies. The domestic listed companies have issued bond financing since 1998. Although the proportion of bond financing amount in the total financing amount has increased in recent years, it is still not very high. Therefore, the bond financing is classified into "Others" category. Through the above analysis, it is not hard to see that China's listed companies have a serious preference for equity financing.

TABLE I. FINANCING STRUCTURE OF LISTED COMPANIES IN CHINA

\begin{tabular}{|c|c|c|c|c|}
\hline Year & $\begin{array}{c}\text { Number of } \\
\text { listed } \\
\text { companies }\end{array}$ & $\begin{array}{c}\text { The } \\
\text { proportion } \\
\text { of equity } \\
\text { financing }\end{array}$ & $\begin{array}{c}\text { The proportion } \\
\text { of liability } \\
\text { financing }\end{array}$ & Others \\
\hline 2009 & 1671 & $32.38 \%$ & $40.67 \%$ & $26.95 \%$ \\
\hline 2010 & 2019 & $25.71 \%$ & $42.89 \%$ & $31.39 \%$ \\
\hline 2011 & 2300 & $24.38 \%$ & $44.67 \%$ & $30.95 \%$ \\
\hline 2012 & 2455 & $31.29 \%$ & $45.71 \%$ & $23.00 \%$ \\
\hline 2013 & 2457 & $26.86 \%$ & $42.86 \%$ & $30.29 \%$ \\
\hline 2014 & 2582 & $30.71 \%$ & $48.57 \%$ & $20.72 \%$ \\
\hline 2015 & 2805 & $29.67 \%$ & $47.56 \%$ & $22.77 \%$ \\
\hline 2016 & 3032 & $25.71 \%$ & $42.86 \%$ & $31.43 \%$ \\
\hline 2017 & 3467 & $27.86 \%$ & $40.63 \%$ & $31.51 \%$ \\
\hline
\end{tabular}

Fund Project: Periodic Research Achievement of Analysis on Recessive Financial Capital of Enterprises' Finance-supporting project for high-level personnel in Xi'an Shiyou University (Project No.: 0109-290088283)

\section{FinANCing Cost Evaluation Index CONSTRUCTION PRINCIPLE}

1. Use methods of quantitative analysis and qualitative analysis. In view of the restrictions of calculation mode and incomprehensiveness of data collected in quantitative analysis, qualitative analysis is required to address those problems.

2. Follow the principle of comprehensiveness and importance. It is necessary to consider both comprehensiveness and importance when selecting indicators.

3. Bear in mind the operability and practicality. The current information processing method must be applicable to data collection and the scientific performance indicator selection, so as to fulfill the ultimate goal of performance evaluation.

4. Adhere to the principle of authenticity and pertinence. The data of the listed companies used in this paper is authentic and reliable, together with which the status quo of domestic listed companies is taken into consideration to design an evaluation index system.

\section{Design Of Evaluation INDEX System OF FINANCING Cost}

Financing cost emerges as the ownership of funds and the right to the use of funds gets separated. In order to obtain the right to use funds, enterprises need to give something satisfying to the fund owner ${ }^{[1]}$. The registration fees, agency fees and service charges involved in the trading by the two sides are the financing charges. Financing cost consists of the fund use fee and the financing cost. As the financing cost is the non-recurring expense and accounts for a small proportion of the total financing, the impact of it on financing cost is not studied in this paper. Whereas, fund use fee is the return that is mainly classified into risk-free return and risk return, paid consecutively by the enterprise to the investors. The interest rate of national debt is generally used as the risk-free rate of return, while the scale of risk return depends on the size and uncertainty of enterprise operating income ${ }^{[2]}$. Therefore, China's listed companies financing cost evaluation index system can be designed from the dimensions of enterprise operating risk, financial risk, operating efficiency and development potential, which are marked as K1, K2, K3 and K4 respectively in the following TABLE II and TABLE III. There are also 11 indexes involved, namely X1: the risk-free rate of return, X2: rate of return on common stockholders' equity, X3: return on total assets ratio, X4: current ratio, X5: 
liability on asset ratio, X6: net profit growth rate, X7: current assets turnover, X8: total assets turnover, the natural logarithm of the final total assets X9, X10: Net Profit Margin on Sales, and X11: Earning Per Share.

TABLE II. CHINA'S LISTED COMPANIES FINANCING COST EVALUATION THIRD CLASS INDEX

\begin{tabular}{|l|c|l|}
\hline Index & Formula & $\begin{array}{l}\text { Correlation } \\
\text { predicted }\end{array}$ \\
\hline X1 & Short-term bond interest rate & $\begin{array}{l}\text { Positive } \\
\text { correlation }\end{array}$ \\
\hline X2 & Current assets/Current liabilities $\times 100 \%$ & $\begin{array}{l}\text { Negative } \\
\text { correlation }\end{array}$ \\
\hline X3 & Total liabilities /Total assets $\times 100 \%$ & $\begin{array}{l}\text { Positive } \\
\text { correlation }\end{array}$ \\
\hline $\mathrm{X} 4$ & Net profit/ The total number of common shares at & $\begin{array}{l}\text { Positive } \\
\text { correlation }\end{array}$ \\
\hline $\mathrm{X} 5$ & Net profit/ (opening net assets+ closing net \\
assets)/2 & $\begin{array}{l}\text { Negative } \\
\text { correlation }\end{array}$ \\
\hline $\mathrm{X} 6$ & Net profit/ (opening net assets + closing net \\
assets)/2 & $\begin{array}{l}\text { Negative } \\
\text { correlation }\end{array}$ \\
\hline $\mathrm{X} 7$ & Net profit /Gross sales $\times 100 \%$ & $\begin{array}{l}\text { Negative } \\
\text { correlation }\end{array}$ \\
\hline $\mathrm{X} 8$ & Sales revenue /Total current asstes $\times 100 \%$ & $\begin{array}{l}\text { Negative } \\
\text { correlation }\end{array}$ \\
\hline $\mathrm{X} 9$ & Sales revenue /Total assets $\times 100 \%$ & $\begin{array}{l}\text { Negative } \\
\text { correlation }\end{array}$ \\
\hline $\mathrm{X} 10$ & $\begin{array}{l}\text { (net profit for the current year }- \text { net profit for last } \\
\text { year) } / \text { net profit for last year } \times 100 \%\end{array}$ & $\begin{array}{l}\text { Negative } \\
\text { correlation }\end{array}$ \\
\hline $\mathrm{X} 11$ & LN (closing net assets) & $\begin{array}{l}\text { Negative } \\
\text { correlation }\end{array}$ \\
\hline
\end{tabular}

comstats China. Therefore, 100 listed companies with the largest market value as of December 31, 2017 in Shanghai and Shenzhen Stock Exchange are selected initially as samples. However, the listed companies in abnormal operation in that year, such as ST, *ST and the one with incomplete financial data are excluded. Finally, the data of 22 enterprises in Shanghai Stock Exchange and 22 enterprises in Shenzhen Stock Exchange from 2017 to 2013, were selected as samples for factor analysis.

\section{B. Correlation test}

The results of correlation test are shown in TABLE IV.

TABLE IV. PEARSON CORRELATION TEST

\begin{tabular}{|c|c|c|c|c|c|c|c|c|c|c|c|}
\hline & $\mathrm{X} 1$ & $\mathrm{X} 2$ & $\mathrm{X3}$ & $\mathrm{X} 4$ & X5 & X6 & $\mathrm{X} 7$ & X8 & X9 & X10 & X11 \\
\hline $\mathrm{X} 1$ & 1 & & & & & & & & & & \\
\hline $\mathrm{X} 2$ & 0.045 & 1 & & & & & & & & & \\
\hline X3 & -0.015 & $-.636 * *$ & 1 & & & & & & & & \\
\hline $\mathrm{X} 4$ & 0.078 & -0.004 & 0.079 & 1 & & & & & & & \\
\hline $\mathrm{X} 5$ & $.465^{* *}$ & 0.054 & 0.037 & $.600^{* * *}$ & 1 & & & & & & \\
\hline X6 & $.458^{* *}$ & $.275^{* *}$ & $-.223 * *$ & $.476^{* *}$ & $.898^{* *}$ & 1 & & & & & \\
\hline X7 & 0.011 & $.299 * *$ & $-.166^{*}$ & $.396 * *$ & $.361 * *$ & $.421 * *$ & 1 & & & & \\
\hline $\mathrm{X} 8$ & -0.045 & $-.340 * *$ & 0.015 & -0.003 & -0.021 & -0.012 & $-.157 *$ & 1 & & & \\
\hline X9 & $.419 * *$ & -0.094 & -0.038 & 0.087 & $.365 * *$ & $.371^{* *}$ & $-.150 *$ & $.488 * *$ & 1 & & \\
\hline $\mathrm{X} 10$ & $-.227 * *$ & $-.201^{* *}$ & $.341^{* *}$ & 0.041 & $-.181^{* *}$ & $-.287 * *$ & -0.042 & 0.023 & $-.208^{* *}$ & 1 & \\
\hline X11 & 0.012 & 0.022 & -0.018 & 0.126 & $.155^{*}$ & $.154^{*}$ & $.414^{* *}$ & $.151^{*}$ & 0.053 & 0.041 & 1 \\
\hline
\end{tabular}

In the above table, the indicator with one “*” in the upper right corner indicates the significance level is 0.01 , and with two “**” represents the significance level of 0.05 . The third indicator is the number of samples ${ }^{[3]}$. In summary, the X1 has a highly significant correlation with X5, X6, X9, and X10 and $\mathrm{X} 2$ has a highly significant correlation with $\mathrm{X} 3, \mathrm{X} 6, \mathrm{X} 7, \mathrm{X} 8$ and X10. X4 has a highly significant correlation with X5, X6 and X7. X5. X5 has a highly significant correlation with X6, $\mathrm{X} 7, \mathrm{X} 8$ and $\mathrm{X} 10$. X6 has a highly significant correlation with $\mathrm{X} 7, \mathrm{X} 9, \mathrm{X} 10$ and X11. The highly significant correlation also exists between X7 and X11, X8 and X9, and X9 and X10. It can be seen that there is a correlation among the 11 financial indicators selected in this paper, and factor analysis can be carried out for these 11 indicators. 


\section{Factor analysis}

1) KMO and Bartlett's Test

$\mathrm{KMO}$ is an indicator of simple correlation and partial correlation among evaluation variables ${ }^{[4]}$. When the square of simple correlation coefficient of all variables is much larger than the square of partial correlation coefficient, KMO will be very close to 1 , which means the variable is very suitable for factor analysis. Oppositely, KMO will be close to 0, and the selected index is not suitable for factor analysis.

TABLE V. KMO AND BARTLETT'S TEST

\begin{tabular}{|c|c|c|}
\hline Kaiser-Meyer-Olkin sample adequacy Measurement & .629 \\
\hline \multirow{3}{*}{ Bartlett test of sphericity } & $\begin{array}{c}\text { The approximate } \\
\text { chi-square }\end{array}$ & 1094.581 \\
\cline { 2 - 3 } & dK & 55 \\
\cline { 2 - 3 } & Significance & .000 \\
\hline
\end{tabular}

In table, the KMO value is 0.629 , falling within the scope of barely suitable for factor analysis. The Bartlett value is
0.000 (under 0.01 ). Above all, the factors from X1 to X11 are applicable for factor analysis.

2) The results of factor analysis

The results of factor analysis are shown in TABLE VI, TABLE VII, TABLE VIII, TABLE IX, TABLE $\mathrm{X}$ and TABLE XI.

TABLE VI. COMMUNALITY

\begin{tabular}{|l|l|l|}
\hline & Initial & Extract \\
\hline $\mathrm{X} 1$ & 1.000 & .592 \\
\hline $\mathrm{X} 2$ & 1.000 & .770 \\
\hline $\mathrm{X} 3$ & 1.000 & .805 \\
\hline $\mathrm{X} 4$ & 1.000 & .625 \\
\hline $\mathrm{X} 5$ & 1.000 & .901 \\
\hline $\mathrm{X} 6$ & 1.000 & .880 \\
\hline $\mathrm{X} 7$ & 1.000 & .756 \\
\hline $\mathrm{X} 8$ & 1.000 & .818 \\
\hline $\mathrm{X} 9$ & 1.000 & .790 \\
\hline $\mathrm{X} 10$ & 1.000 & .485 \\
\hline $\mathrm{X} 11$ & 1.000 & .646 \\
\hline
\end{tabular}

TABLE VII. TOTAL NUMBER OF VARIANCES EXPLAINED

\begin{tabular}{|c|c|c|c|c|c|c|c|c|c|}
\hline \multirow{2}{*}{ Component } & \multicolumn{3}{|c|}{ Initial eigenvalue } & \multicolumn{3}{|c|}{ Extraction sums of squared loadings } & \multicolumn{3}{|c|}{ Rotation sums of squared loadings } \\
\hline & Total & Variance \% & Accumulation \% & Total & Variance \% & Accumulation \% & Total & Variance \% & Accumulation \% \\
\hline 1 & 3.184 & 28.950 & 28.950 & 3.184 & 28.950 & 28.950 & 2.769 & 25.173 & 25.173 \\
\hline 2 & 1.971 & 17.922 & 46.872 & 1.971 & 17.922 & 46.872 & 1.971 & 17.920 & 43.092 \\
\hline 3 & 1.668 & 15.163 & 62.034 & 1.668 & 15.163 & 62.034 & 1.677 & 15.244 & 58.336 \\
\hline 4 & 1.243 & 11.304 & 73.338 & 1.243 & 11.304 & 73.338 & 1.650 & 15.002 & 73.338 \\
\hline 5 & .825 & 7.496 & 80.833 & & & & & & \\
\hline 6 & .711 & 6.461 & 87.294 & & & & & & \\
\hline 7 & .397 & 3.608 & 90.902 & & & & & & \\
\hline 8 & .374 & 3.396 & 94.298 & & & & & & \\
\hline 9 & .323 & 2.937 & 97.235 & & & & & & \\
\hline 10 & .235 & 2.137 & 99.372 & & & & & & \\
\hline 11 & .069 & .628 & 100.000 & & & & & & \\
\hline
\end{tabular}

In TABLE VI, the initial values of $\mathrm{X} 1$ to $\mathrm{X} 11$ are all set as unit 1 , and the extract ratios are 0.592, $0.770 \ldots 0.646$ respectively. The extract quantity is seen in TABLE VI. It can be seen in the TABLE VII that the contribution rate of component 1 is highest one, with $28.950 \%$. The cumulative contribution rate of component 1, 2, 3 and 4 is $77.338 \%$, which means that the four components could explain $77.338 \%$ of all variables, and then suggests that they can be extracted as the primary factor.

TABLE VIII. COMPONENT MATRIX

\begin{tabular}{|c|c|c|c|c|}
\hline & \multicolumn{4}{|c|}{ Component } \\
\cline { 2 - 5 } & 1 & 2 & 3 & 4 \\
\hline $\mathrm{X} 6$ & .934 & .031 & -.020 & -.082 \\
\hline $\mathrm{X} 5$ & .872 & .248 & .178 & -.219 \\
\hline $\mathrm{X} 4$ & .575 & .158 & .511 & -.087 \\
\hline $\mathrm{X} 7$ & .555 & -.357 & .500 & .265 \\
\hline $\mathrm{X} 1$ & .534 & .297 & -.314 & -.347 \\
\hline $\mathrm{X} 2$ & .387 & -.741 & -.256 & .073 \\
\hline $\mathrm{X} 9$ & .390 & .619 & -.464 & .197 \\
\hline $\mathrm{X} 3$ & -.302 & .585 & .503 & -.345 \\
\hline $\mathrm{X} 10$ & -.396 & .126 & .559 & .017 \\
\hline $\mathrm{X} 11$ & .277 & .020 & .371 & .657 \\
\hline $\mathrm{X} 8$ & -.047 & .614 & -.206 & .629 \\
\hline
\end{tabular}

The factor loading of variable X6 in component 1 is very high, reaching at 0.934 , so we can attribute X6 to component 1 . However, the factor loading of variable $\mathrm{X} 8$ in component 3 is
0.614, and in component 4 is 0.629 , both of which are relatively high and close to each other.

TABLE IX. ROTATION COMPONENT MATRIX

\begin{tabular}{|c|c|c|c|c|}
\hline \multirow{2}{*}{} & \multicolumn{4}{|c|}{ Component } \\
\cline { 2 - 5 } & 1 & 2 & 3 & 4 \\
\hline $\mathrm{X} 5$ & .926 & .003 & .024 & .205 \\
\hline $\mathrm{X} 6$ & .851 & -.317 & .044 & .231 \\
\hline $\mathrm{X} 1$ & .669 & -.120 & .175 & -.315 \\
\hline $\mathrm{X} 4$ & .610 & .233 & -.125 & .428 \\
\hline $\mathrm{X} 3$ & .074 & .886 & -.034 & -.117 \\
\hline $\mathrm{X} 2$ & .078 & -.794 & -.332 & .150 \\
\hline $\mathrm{X} 10$ & -.281 & .574 & -.171 & .217 \\
\hline $\mathrm{X} 8$ & -.126 & .125 & .872 & .158 \\
\hline $\mathrm{X} 9$ & .411 & -.090 & .767 & -.155 \\
\hline $\mathrm{X} 11$ & .006 & -.017 & .250 & .764 \\
\hline $\mathrm{X} 7$ & .303 & -.182 & -.274 & .746 \\
\hline
\end{tabular}

The component 1, 2, 3 and 4 are coded as K1, K2, K3, and $\mathrm{K} 4$ for measurement. The factor loading of $\mathrm{K} 1$ in $\mathrm{X} 1$ is 0.669 , the largest. The largest factor loading value of K2 in X2 is -0.794 and in $\mathrm{X} 3$ is 0.88 . The largest factor loading value of $\mathrm{K} 1$ in X4, X5 and X6 are 0.610, 0.926 and 0.851 respectively. In $\mathrm{X} 7, \mathrm{~K} 4$ has the largest factor loading value 0.746 . In $\mathrm{X} 8$ and $\mathrm{X} 9$, K3 has the largest factor loading value 0.872 and 0.767 . In $\mathrm{X} 10, \mathrm{~K} 2$ has the largest factor loading value 0.574 . In X11, K4 has the largest factor loading value 0.746 . 
To sum up, factors like X1, X4, X5, X6 are assigned to K1. $\mathrm{X} 2, \mathrm{X} 3, \mathrm{X} 10$ belong to K2. Factors X8 and X9 belong to K3. $\mathrm{X} 7$ and $\mathrm{X} 11$ are assigned to K4. The data analysis of the main factors $\mathrm{K} 1, \mathrm{~K} 2$, K3 and K4 is shown in TABLE 10.

TABLE $X$. COMPONENT SCORE COEFFICIENT MATRIX

\begin{tabular}{|c|c|c|c|c|}
\hline & \multicolumn{4}{|c|}{ Component } \\
\cline { 2 - 5 } & 1 & 2 & 3 & 4 \\
\hline $\mathrm{X} 1$ & .289 & -.016 & .035 & -.281 \\
\hline $\mathrm{X} 2$ & -.035 & -.396 & -.151 & .051 \\
\hline $\mathrm{X} 3$ & .132 & .482 & -.093 & -.079 \\
\hline $\mathrm{X} 4$ & .226 & .195 & -.106 & .194 \\
\hline $\mathrm{X} 5$ & .351 & .090 & -.044 & .016 \\
\hline $\mathrm{X} 6$ & .285 & -.090 & -.003 & .041 \\
\hline $\mathrm{X} 7$ & .032 & -.043 & -.120 & .426 \\
\hline $\mathrm{X} 8$ & -.132 & .002 & .559 & .196 \\
\hline $\mathrm{X} 9$ & .117 & -.059 & .437 & -.091 \\
\hline $\mathrm{X} 10$ & -.075 & .294 & -.101 & .172 \\
\hline $\mathrm{X} 11$ & -.119 & -.015 & .221 & .522 \\
\hline
\end{tabular}

According to TABLE 11, the linear relationship between the four main factors and the 11 independent variables is obtained.
$\mathrm{K} 1=0.289 * \mathrm{X} 1-0.035 * \mathrm{X} 2+0.132 * \mathrm{X} 3+0.226 \mathrm{X} * 4+0.351 * \mathrm{X} 5$ $+0.285 * \mathrm{X} 6+0.032 * \mathrm{X} 7-0.132 * \mathrm{X} 8+0.117 * \mathrm{X} 9-0.075 * \mathrm{X} 10-0.119$ *X11

$\mathrm{K} 2=-0.016 * \mathrm{X} 1-0.396 * \mathrm{X} 2+0.482 * \mathrm{X} 3+0.195 * \mathrm{X} 4+0.090 * \mathrm{X}$ $5+-0.090 * X 6+-0.043 * X 7+0.002 * X 8-0.059 * X 9+0.294 * X 10-0$. $015 * \mathrm{X} 11$

$\mathrm{K} 3=0.035 * \mathrm{X} 1-0.151 * \mathrm{X} 2-0.093 * \mathrm{X} 3-0.106 * \mathrm{X} 4-0.044 * \mathrm{X} 5-0$ $.003 * \mathrm{X} 6-0.120 * \mathrm{X} 7+0.559 * \mathrm{X} 8+0.437 * \mathrm{X} 9-0.101 * \mathrm{X} 10+0.221 *$ $\mathrm{X} 11$

$\mathrm{K} 4=-0.281 * \mathrm{X} 1+0.051 * \mathrm{X} 2-0.079 * \mathrm{X} 3+0.194 * \mathrm{X} 4+0.016 * \mathrm{X}$ $5+0.041 * \mathrm{X} 6+0.426 * \mathrm{X} 7+0.196 * \mathrm{X} 8-0.091 * \mathrm{X} 9+0.172 * \mathrm{X} 10+0.5$ $22 * \mathrm{X} 11$

On this basis, the ratio of the variance contribution rate of each factor to the total variance of the four factors is weighted as the weight, and the comprehensive performance score $\mathrm{k}$ of the sample enterprise is obtained as follows:

\section{$\mathrm{K}=30.21 \% \mathrm{~K} 1+26.15 \% \mathrm{~K} 2+22.31 \% \mathrm{~K} 3+21.33 \% \mathrm{~K} 4$}

According to formula $\mathrm{k}$ of comprehensive score, the comprehensive score of financing cost of 44 enterprises from 2017 to 2013 can be estimated. This paper showcases the comprehensive score of financing cost of 44 enterprises in 2017, as shown in TABLE XI.

TABLE XI. THE COMPREHENSIVE EVALUATION OF FINANCING COST IN 2017

\begin{tabular}{|c|c|c|c|c|c|c|}
\hline No. & Companies & K1 & $\mathrm{K} 2$ & K3 & K4 & $\bar{K}$ \\
\hline 1 & Yunan Aluminum & -0.906654 & 7.206522 & -1.570698 & 4.514007 & 2.223020 \\
\hline 2 & Zhongnan Construction & -0.744797 & 7.452308 & -2.681788 & 3.537918 & 1.880106 \\
\hline 3 & Inspur Group & -0.618077 & 6.576027 & -1.953060 & 3.399387 & 1.822272 \\
\hline 4 & Avic Electromechanical & -0.593518 & 6.673895 & -2.418115 & 3.147025 & 1.697701 \\
\hline 5 & GRG Banking & -0.596123 & 5.812254 & -2.616880 & 3.271458 & 1.453792 \\
\hline 6 & Holitech & -0.598624 & 6.660165 & -2.254618 & 3.356725 & 1.773773 \\
\hline 7 & Oriental Energy & -0.666021 & 6.773455 & -1.781570 & 3.956864 & 2.016585 \\
\hline 8 & Binjiang Real Estate & -0.529562 & 7.132979 & -2.658254 & 3.512996 & 1.861559 \\
\hline 9 & BROAD-OCEAN MOTOR & -0.588557 & 6.517884 & -2.359398 & 3.010598 & 1.642402 \\
\hline 10 & Bicon Pharmaceutical Group & -0.514741 & 6.454525 & -2.594157 & 3.232341 & 1.643057 \\
\hline 11 & Victory Precision & -0.614825 & 6.625689 & -2.204717 & 3.088890 & 1.713867 \\
\hline 12 & Kangdexin & -0.562780 & 6.569229 & -2.612568 & 3.533352 & 1.718638 \\
\hline 13 & Luxshare Precision & -0.600197 & 6.728212 & -2.217687 & 3.518113 & 1.833755 \\
\hline 14 & Souyute & -0.686498 & 6.069624 & -1.801053 & 3.588637 & 1.743457 \\
\hline 15 & Hytera & -0.524294 & 6.662064 & -2.366918 & 2.816534 & 1.656448 \\
\hline 16 & Lomon Billions & -0.924080 & 6.810649 & -1.308289 & 5.879151 & 2.463964 \\
\hline 17 & Kaujingtong & -0.597142 & 5.952265 & -1.968066 & 3.550599 & 1.694388 \\
\hline 18 & MLS & -0.351282 & 7.109213 & -2.326873 & 3.496035 & 1.979516 \\
\hline 19 & Lepu Medical & -0.527396 & 6.452271 & -2.331935 & 3.374418 & 1.727451 \\
\hline 20 & WALVAX Biotechnology & 1.630806 & 6.394410 & -6.545428 & -7.823549 & -0.964243 \\
\hline 21 & Jetsen & -0.554321 & 6.418816 & -2.428342 & 3.263735 & 1.665452 \\
\hline 22 & Techand & -0.544956 & 6.846697 & -2.300633 & 3.395489 & 1.836767 \\
\hline 23 & Xingyuan Environment & -0.599000 & 6.435818 & -2.185637 & 3.513799 & 1.763886 \\
\hline 24 & Sungrow Power & -0.554017 & 6.573495 & -2.264441 & 3.653154 & 1.825621 \\
\hline 25 & Leyard & -0.506641 & 6.612683 & -2.193839 & 3.626878 & 1.860328 \\
\hline 26 & Mengcao & -0.590897 & 6.665295 & -2.081693 & 3.841548 & 1.919441 \\
\hline 27 & East & -0.554123 & 6.628554 & -2.110708 & 3.302604 & 1.799513 \\
\hline 28 & Lens Technology & -0.607728 & 6.970572 & -2.121521 & 3.737181 & 1.963039 \\
\hline 29 & Kingfa Technology & -0.599011 & 6.569978 & -2.221273 & 3.030211 & 1.687866 \\
\hline 30 & Juhua & -1.257953 & 5.561846 & -1.191238 & 5.954493 & 2.078723 \\
\hline 31 & Heungkong Holding & -0.595103 & 6.568484 & -2.449831 & 3.316549 & 1.698740 \\
\hline 32 & Luenmei Holding & -0.476994 & 5.474451 & -2.843679 & 3.636431 & 1.428695 \\
\hline 33 & Meidu & -0.622123 & 6.585645 & -2.340945 & 2.923709 & 1.635565 \\
\hline 34 & Nanshan Aluminum & -0.770105 & 6.503285 & -2.417012 & 3.496651 & 1.674561 \\
\hline 35 & BTG Hotels & -0.641261 & 7.056256 & -1.584080 & 3.848827 & 2.119033 \\
\hline 36 & Baiyunshan & -0.472763 & 6.372044 & -2.562284 & 3.674864 & 1.735671 \\
\hline 37 & Anhui Jianghuai Automobile & -0.566372 & 7.112597 & -2.369472 & 2.793904 & 1.756154 \\
\hline
\end{tabular}




\begin{tabular}{|l|l|l|l|l|l|l|}
\hline \multicolumn{7}{|c|}{ Cont. to TABLE XI } \\
\hline 38 & CSIC & -0.605358 & 6.428804 & -2.662502 & 3.478371 & 1.646186 \\
\hline 39 & Fujian Funeng & -0.531261 & 6.547726 & -2.440670 & 3.152628 & 1.679678 \\
\hline 40 & Shanying Intel & -1.094442 & 7.004269 & -1.124695 & 5.671866 & 2.459875 \\
\hline 41 & Taiji Industry & -0.603622 & 6.672746 & -2.180004 & 3.271278 & 1.773974 \\
\hline 42 & Bailian Group & -0.627247 & 7.177540 & -2.063559 & 3.389982 & 1.950138 \\
\hline 43 & Maoye & -0.635824 & 7.097119 & -1.606712 & 3.765413 & 2.108519 \\
\hline 44 & Lingang Group & -0.556977 & 6.195542 & -2.584143 & 3.187820 & 1.555311 \\
\hline
\end{tabular}

\section{CONCLUSIONS}

1. TABLE VII shows that the contribution rates of the four main factors $\mathrm{K} 1, \mathrm{~K} 2, \mathrm{~K} 3$ and $\mathrm{K} 4$ through factor analysis are $28.950 \%, 17.922 \%, 15.163 \%$ and $11.304 \%$ respectively. Among them, K1 has the highest figure, which can be construed that the impact of $\mathrm{K} 1$ on the financing cost of enterprises is the largest one. That is to say, the most influential factor the financing cost of enterprises is the operating risk, followed by the financial risk factor and operational efficiency factor, and the least influential one is development potential.

2. From Table XI, following conclusions can be drawn. (1) factors scoring below -1.17 indicate that they are strong to reduce financing cost. If the score is above -0.55 , the factor has a strong ability to raise financing cost; (2) if scoring below 5 points, the financial risk factor has a strong capability to reduce financing cost, while scoring above 7 points indicate that the factor has a strong ability to raise financing cost; (3) as for the operating efficiency factor, if scoring below -2.8, it has a strong ability to reduce financing cost. Whereas the score above -1.8 indicates that the factor has a strong ability to improve financing cost; the score of development potential factor is below 2 points, indicating that the factor has a strong ability to reduce financing cost, and the score above 4 points embodies that the factor has a strong ability to improve financing cost

\section{REFERENCES}

[1] Klein J, Gee D, Jones H. Analyzing Clusters of Skills in R\&D Core Competence[J]. R\&D Management, 1998(1):37-42

[2] Gallon M., Klein D. Putting core competence into practiced[J]. Research Technology Management, 1995(5):20-28

[3] Durand T. Strategizing for Innovation: Competence Analysis in Assessing Strategic Change[J]. Competence-based Strategic Management, 1995(3): 127-150

[4] C. K. Prahalad, Gary Hamel. The Core Competence of the Corporation[J]. Harvard Business Review, 1990(5):79-91 